\title{
Operationalization of Internal Analysis Using the VRIO Framework: Development of Scale for Resource and Capabilities Organization (Case Study: XYZ Company Animal Feed Business Unit)
}

\author{
Widya Ariyani ${ }^{1 \rtimes}$ \\ Arief Daryanto $^{2}$ \\ Sahara $^{3}$ (iD
}

${ }^{1,2}$ School of Business. Bogor Agricultural University Jl. Raya Pajajaran, Bogor 16151, Indonesia ${ }^{2}$ Email: roidyaariyani2112@yahoo.com ${ }^{2}$ Email: adaryant@yahoo.com

${ }^{s}$ Departement of Economic. Faculty of Economics and Management. Bogor Agicultural University. Jl. Lingkar Kampus-Kampus IPB Darmaga, Bogor 16680, Indonesia ${ }^{3}$ Email:sahara_ipb@yahoo.com

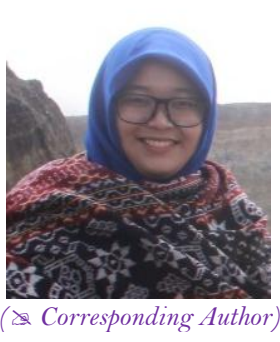

(A) Check for updates

\begin{abstract}
Finding the source of competitive advantage has become an essential area in the research of strategic management. One of the methods commonly used to find out the competitive advantage is by conducting internal analysis using the VRIO framework. The weaknesses of said framework are that they cannot be used to determine how strong the competitive advantage of the company can be managed by them. Therefore the objectives of this paper are to create assessment scales to determine how well the resources or capabilities has been managed by the company in a VRIO framework. To elaborate on the operationalizing of VRIO scale, a case study in the animal feed business unit of XYZ Company was used.
\end{abstract}

Keywords: Internal analysis, Resource based view, Operationalizing the VRIO scale, Value chain Analysis, Animal feed business unit JEL Classification: M20; Q12.

\section{Introduction}

In the early 1950s-1960s, strategy was centered on the planning process and gradual execution processes (Grant, 2013). However, the strategic planning process in business today puts forward the dynamic of external environment. Therefore most of the companies prefer to implement planning process using the market based approach (Sirmon et al., 2007). The most popular theory of market-based approach used is the Porter's Five Forces. It is a powerful tool for understanding the competitiveness of business environment, and to identify our strategy's potential profitability where strategy-making is done by taking external factors into account.

Lack of attention to internal analysis in strategic management of asset has created a new paradigm: Resource Based View (Wernerfelt, 1984; Barney, 1991; Grant, 1991; Peteraf, 1993). Resource Based View sees a company as a collection of resources and capabilities (Wernerfelt, 1984). Resources consist of both tangible assets such as financial assets and physical assets, as well as intangible assets such as human resources, patents and technology (Grant, 1991; Amit and Schoemaker, 1993). An organizational capability is defined as the company's ability to manage resources in achieving the desired goals (Amit and Schoemaker, 1993). Capability is not included in tangible assets or intangible assets, but rather a "intangible asset" that cannot be easily imitated by purchase but must be built by the company itself (Teece et al., 1997).

Based on the explanation above, we will make two basic assumptions that Resource Based View are resource heterogeneity and resource immobility (Mata et al., 1995). First the heterogeneity assumption means the quality of being made of many different elements, forms, kinds, or different productive resources between companies; whereas the immobility assumptions considered resources are very expensive, difficult to imitate and inelastic in supply. However, it is impossible to define a set of resources that provide a universal competitive advantage because each company's resources have a specific context (Barney, 2001; Wernerfelt, 2013).

Barney (1991) was the first to attempt to formalize the Resource Based View theory by creating four assessment criteria, namely valuable, rare, imperfectly imitable and non-substitutable. These criteria are often referred to as the VRIN framework (Barney, 1991). However, it is impossible to define a set of resources that provide a universal competitive advantage. The reason as each company's resources has a specific context. Barney's competitive advantages are as follow: valuable resources if they can be utilized to improve efficiency and effectiveness, or in other words: it must take advantage of an opportunity or neutralize threats within the corporate environment. Resources are considered very rarely owned (rare) if not owned by a competitor company or at least, only a few competing companies. Resources cannot be imitated perfectly (imitability) whenever it is impossible or 
substantially difficult for competitors to replicate. And finally, resources cannot be offset if no other asset can meet the same or similar strategic value.

The VRIN framework received criticism because the criteria used could neither explain the differences in each company's performance (Newbert, 2007; Kraaijenbrik et al., 2010) nor explain how (Mohamad and Norezam, 2012) and when (Kraaijenbrik et al., 2010) the resources and capabilities are built or how well they are managed. Therefore, Barney (1995) corrected it by converting it to VRIO. "O" stands for organization means the ability or condition necessary to materialize the competitive value of an identified resource or capability. If valuable, rare and imperfect resources or capabilities can be replicated, companies need to be set up to manage them and utilize them. The weakness of using the VRIO framework is when used to compare performance in managing resources/capabilities between 2 or more firms (Knot, 2015). Therefore this journal will discuss the use of scale in measuring the level of "organization" of a resource/capability of a company within the VRIO framework.

\section{The Concept of Resource Based View}

Resource Based View is a reference or framework for conducting internal analysis by learning all of the resources and capabilities owned and controlled by the company. Internal resources of the company can be classified into four categories: physical resources (Williamson, 1975) human resources (Becker, 1964) organizational resources (Tomer, 1987) and financial resources (David, 2013). Physical resources are physical infrastructure used by the companies, structures, buildings and factories, equipment, geographical location or place and access to raw materials. Human resources include expertise, education and knowledge as well as skills development program for every workers within a company. Organizational resources include the company's formal reporting structure, formal and informal planning, control systems, coordination systems, culture and reputation, informal relationships between groups within companies, between companies and the environment. Financial resources include all the financial resources that a company can use to generate and implement a strategy.

We can use value chain approach to identify the resources and capabilities of internal company. In the value chain approach, production activities are divided into two, namely support activities and primary activities. Porter (1998) in his book describes primary activities are activities directly involved in products and services, while support activities are activities that ensure that the main activities can be done efficiently and effectively.

\subsection{Identification of Competitive Advantage Using the VRIO Framework}

By utilizing the value chain model, an identification technique for competitive advantage based on the valuation using VRIO framework is developed. The VRIO framework is structured with a number of questions about resources and capabilities, using four indicators of valuability, rarity, imitability and organization.

The four questions used to analysis the VRIO framework, are as follows:

a) Valuable: whether these resources/capabilities can encourage companies to make the operation process more efficient and effective, or can be used to exploit external opportunities or counteract threats.

b) Rare: whether the resources/capabilities are controlled only by a small number of companies or rarely owned by other companies.

c) Imitability: whether the resources/capabilities are hard to imitate or replicate by other companies.

d) Organization: whether the resources/capabilities are supported and managed by the company appropriately.

According to Chaharbaghi and Lynch (1999) sustainability in gaining the competitive advantage is how a company can manage and enhance the resources or ability to achieve new forms of competitive advantage. According to Ghemawat (1986) the competitive advantage based on its source can be divided into 3 categories, namely (1). Targeted market size, (2). Primary access to resources or consumers, and (3). Limitation of choice of competitors. Based on those categories, there are two competitive advantages that are derived from resources which are (1). Superior access to resources, and (2). Limiting options for competitors.

Therefore, in order to obtain sustainable competitive advantage, a resource or capability should be: (1). Rarely owned by another company, (2). difficult to obtain / hard to imitate by other companies, and (3). Will be wellmanaged by the company.

Based on the explanation above, the use of VRIO framework is very appropriate to be used in searching for sustainable competitive advantage. The disadvantages of the VRIO framework they are unable to provide assessment for the third sustainable competitiveness criteria which could be well-managed by the company. Therefore, for the fourth question point of "organization", it can be combined with the Likert scale (1-4) to demonstrate the assessment score of a company's ability to manage the said resources/capabilities.

\section{Case Study of XYZ Company}

The following tables are examples of internal environment analysis using resource based view. To identify the resources and capabilities as competitive advantage, we can use value chain analysis combined with VRIO framework.

\subsection{Value Chain Analysis}

Based on the 'Value Chain' framework of the porter, the activities took place at XYZ Company can be divided into two groups: primary activities and support activities, they are presented in Figure 1. Primary activities are an activities that have an immediate effect on the production, maintenance, sales and support of the products or services to be supplied. Meanwhile, supporting activities assist the primary activities and they form the basis of any organization 


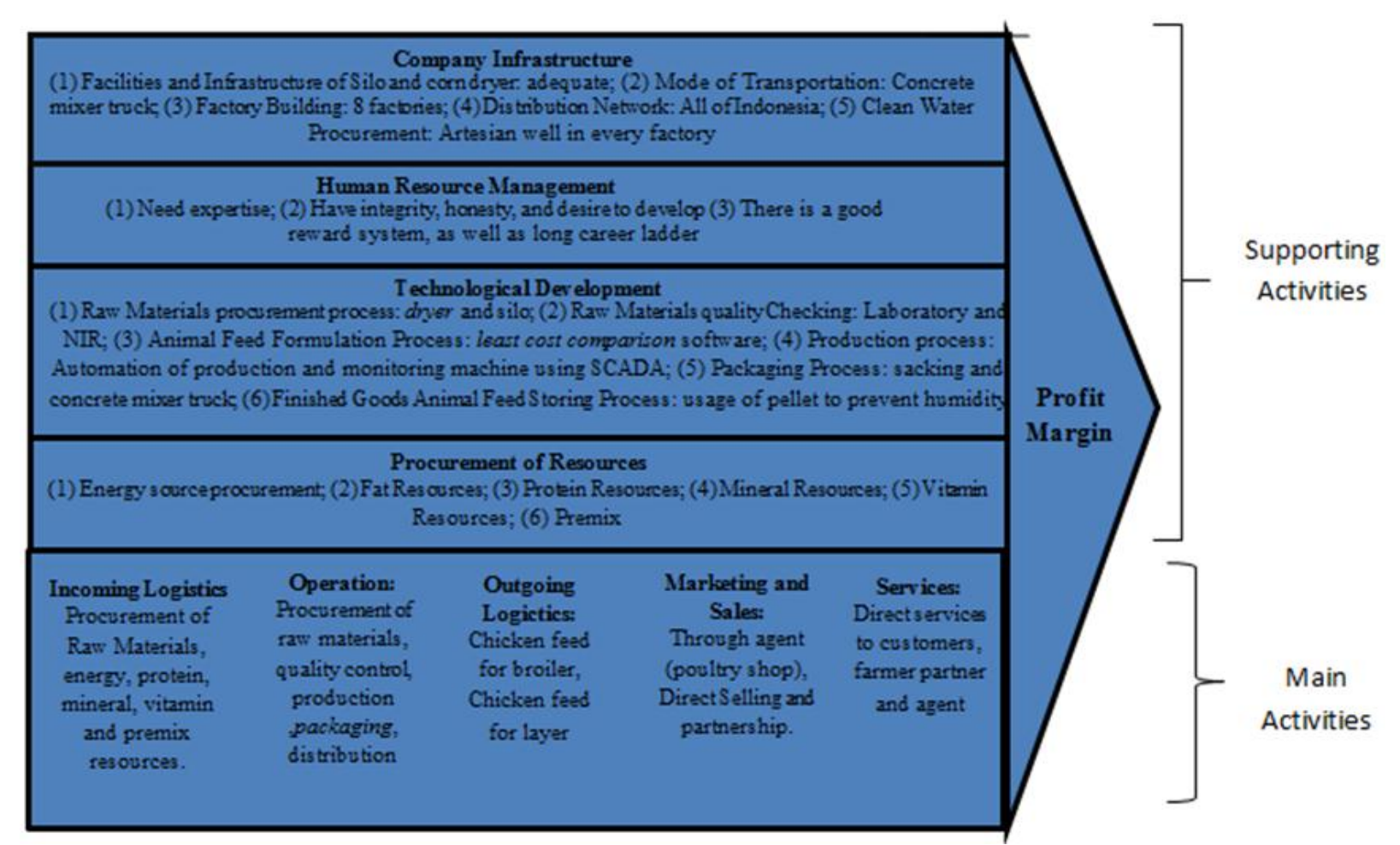

Source: Researcher's approach, 2018

Figure-1. Value Chain Analysis of XYZ Company

\subsection{VRIO Test}

After all the resources and capabilities used in each part of the XYZ Company on animal feed business are identified, the next step is to conduct an analysis using the layered analysis of VRI Test (Value Rarity, and imitability) they are presented in Table 1.

Table-1. VRI Analysis

\begin{tabular}{|c|c|c|c|c|c|}
\hline Resource/Capability & $\mathbf{V}$ & $\mathbf{R}$ & I & Strengths or Weaknesses & $\begin{array}{l}\text { Economicat } \\
\text { Performance }\end{array}$ \\
\hline $\begin{array}{l}\text { Clear Mission and Objective of the Animal Feed } \\
\text { Business Unit }\end{array}$ & $\sqrt{ }$ & $\sqrt{ }$ & - & $\begin{array}{l}\text { Temporary Competitive } \\
\text { Advantage }\end{array}$ & $\begin{array}{l}\text { Above } \\
\text { Normal }\end{array}$ \\
\hline Big Corporate Loan capacity & $\sqrt{ }$ & $\sqrt{ }$ & - & $\begin{array}{l}\text { Temporary Competitive } \\
\text { Advantage }\end{array}$ & $\begin{array}{l}\text { Above } \\
\text { Normal }\end{array}$ \\
\hline Big corporate asset and capital & $\sqrt{ }$ & $\sqrt{ }$ & - & $\begin{array}{l}\text { Temporary Competitive } \\
\text { Advantage }\end{array}$ & $\begin{array}{l}\text { Above } \\
\text { Normal }\end{array}$ \\
\hline Advanced factory technology and facility & $\sqrt{ }$ & - & - & Competitive Parity & Normal \\
\hline Good spatial arrangement of the animal feed factory & $\sqrt{ }$ & - & - & Competitive Parity & Normal \\
\hline Strategic location of the animal feed factory & $\sqrt{ }$ & - & - & Competitive Parity & Normal \\
\hline $\begin{array}{l}\text { The reliable capability of } \mathrm{R} \& \mathrm{D} \text { in creating livestock } \\
\text { feed formula }\end{array}$ & $\sqrt{ }$ & $\sqrt{ }$ & $\sqrt{ }$ & $\begin{array}{l}\text { Proceed to organization } \\
\text { analysis }\end{array}$ & $\begin{array}{l}\text { Above } \\
\text { Normal }\end{array}$ \\
\hline Qualified and well experienced experts of the company & $\sqrt{ }$ & $\sqrt{ }$ & - & $\begin{array}{l}\text { Temporary Competitive } \\
\text { Advantage }\end{array}$ & $\begin{array}{l}\text { Above } \\
\text { Normal }\end{array}$ \\
\hline Loyalty of the company employees & $\sqrt{ }$ & - & - & Competitive Parity & Normal \\
\hline Employees motivation & $\sqrt{ }$ & - & - & Competitive Parity & Normal \\
\hline Sophistication of finished goods technology & $\sqrt{ }$ & - & - & Competitive Parity & Normal \\
\hline $\begin{array}{lllll}\begin{array}{l}\text { Sophistication of raw materials quality control } \\
\text { technology }\end{array} & & & \\
\end{array}$ & $\sqrt{ }$ & $\sqrt{ }$ & - & $\begin{array}{l}\text { Temporary Competitive } \\
\text { Advantage }\end{array}$ & $\begin{array}{l}\text { Above } \\
\text { Normal }\end{array}$ \\
\hline $\begin{array}{l}\text { Sophistication of finished goods quality control } \\
\text { technology }\end{array}$ & $\sqrt{ }$ & - & - & Competitive Parity & Normal \\
\hline Supplier loyalty & $\sqrt{ }$ & - & - & Competitive Parity & Normal \\
\hline Raw materials transportation system & $\sqrt{ }$ & - & - & Competitive Parity & Normal \\
\hline Big raw materials warehouse storage capacity & $\sqrt{ }$ & $\sqrt{ }$ & - & $\begin{array}{l}\text { Temporary Competitive } \\
\text { Advantage }\end{array}$ & $\begin{array}{l}\text { Above } \\
\text { Normal }\end{array}$ \\
\hline Big production capacity of the company & $\sqrt{ }$ & $\sqrt{ }$ & - & $\begin{array}{l}\text { Temporary Competitive } \\
\text { Advantage }\end{array}$ & $\begin{array}{l}\text { Above } \\
\text { Normal }\end{array}$ \\
\hline Good administration of the company & $\sqrt{ }$ & - & - & Competitive Parity & Normal \\
\hline $\begin{array}{l}\text { The lack of adequate transportation infrastructure for } \\
\text { animal feed distribution }\end{array}$ & - & - & - & Competitive Disadvantage & $\begin{array}{l}\text { Below } \\
\text { Normal }\end{array}$ \\
\hline Finished Goods warehouse storage capacity & $\sqrt{ }$ & - & - & Competitive Parity & Normal \\
\hline $\begin{array}{l}\text { A strong brand identity has been recognized in a longer } \\
\text { time as high quality animal feed producer }\end{array}$ & $\sqrt{ }$ & $\sqrt{ }$ & $\sqrt{ }$ & $\begin{array}{l}\text { Proceed to organization } \\
\text { analysis }\end{array}$ & $\begin{array}{l}\text { Above } \\
\text { Normal }\end{array}$ \\
\hline Credit Term is too short & - & - & - & Competitive Disadvantage & $\begin{array}{l}\text { Below } \\
\text { Normal }\end{array}$ \\
\hline Products pricing is the most expensive in its class & - & - & - & Competitive Disadvantage & $\begin{array}{l}\text { Below } \\
\text { Normal } \\
\end{array}$ \\
\hline An extensive marketing networks & $\sqrt{ }$ & $\sqrt{ }$ & $\sqrt{ }$ & $\begin{array}{l}\text { Proceed to organization } \\
\text { analysis }\end{array}$ & $\begin{array}{l}\text { Above } \\
\text { Normal }\end{array}$ \\
\hline Position as market leader & $\sqrt{ }$ & $\sqrt{ }$ & - & $\begin{array}{l}\text { Temporary Competitive } \\
\text { Advantage }\end{array}$ & $\begin{array}{l}\text { Above } \\
\text { Normal }\end{array}$ \\
\hline Product assurance and guarantee & $\sqrt{ }$ & - & - & Competitive Parity & Normal \\
\hline
\end{tabular}




\begin{tabular}{|c|c|c|c|c|c|}
\hline Technical support reliable and well experienced & $\sqrt{ }$ & $\sqrt{ }$ & $\sqrt{ }$ & $\begin{array}{l}\text { Proceed to organization } \\
\text { analysis }\end{array}$ & $\begin{array}{l}\text { Above } \\
\text { Normal }\end{array}$ \\
\hline CSR to the community/academic/farmers & $\sqrt{ }$ & - & - & Competitive Parity & Normal \\
\hline Good corporate financial management capability & $\sqrt{ }$ & $\sqrt{ }$ & $\sqrt{ }$ & $\begin{array}{l}\text { Proceed to organization } \\
\text { analysis }\end{array}$ & $\begin{array}{l}\text { Above } \\
\text { Normal }\end{array}$ \\
\hline $\begin{array}{l}\text { Ability for retaining company employees } \\
\text { Hijacking }\end{array}$ & $\sqrt{ }$ & - & - & Competitive Parity & Normal \\
\hline $\begin{array}{l}\text { Ability to improve the quality of employees skill } \\
\text { (training, seminars, etc.) }\end{array}$ & $\sqrt{ }$ & - & - & Competitive Parity & Normal \\
\hline $\begin{array}{l}\text { Ability to adopt the latest Information Technology } \\
\text { system }\end{array}$ & $\sqrt{ }$ & - & - & Competitive Parity & Normal \\
\hline Ability to anticipate raw material price volatility & $\sqrt{ }$ & $\sqrt{ }$ & - & $\begin{array}{l}\text { Temporary Competitive } \\
\text { Advantage }\end{array}$ & $\begin{array}{l}\text { Above } \\
\text { Normal }\end{array}$ \\
\hline $\begin{array}{l}\text { Lack of ability to continuously obtain high quality raw } \\
\text { materials }\end{array}$ & - & - & - & Competitive Disadvantage & $\begin{array}{l}\text { Below } \\
\text { Normal }\end{array}$ \\
\hline Speed in unloading of raw materials & $\sqrt{ }$ & - & - & Competitive Parity & Normal \\
\hline Ability to improve production efficiency & $\sqrt{ }$ & - & - & Competitive Parity & Normal \\
\hline The lack of ability to promote the product & - & - & - & Competitive Disadvantage & $\begin{array}{l}\text { Below } \\
\text { Normal }\end{array}$ \\
\hline
\end{tabular}

We can categorize the strengths or weaknesses of a company's resources or capabilities based on its competitive and economic performance. Table 4 revealed that the business unit of XYZ Company has some weaknesses, among others: (1). The lack of adequate transportation infrastructure for animal feed distribution, (2). Credit Term is too short, (3). Products pricing is the most expensive in its class, (4). Lack of ability to continuously obtain high quality raw materials, and (5). The lack of ability to promote the product.

Meanwhile, the strategic strengths are: (1). Clear Mission and Objective of the Animal Feed Business, (2). Big Corporate Loan capacity, (3). Big corporate asset and business capital, (4). The reliable capability of R\&D in creating livestock feed formula, (5). Qualified and experienced experts of the company, (6). Sophistication of raw materials quality control technology, (8). Big production capacity of the company, (9). A strong brand identity has been recognized in a longer time as high quality animal feed producer, (11). Position as market leader, (12). Technical support services reliable and well experienced, (13). Good corporate financial management capabilities, and (14). Ability to anticipate raw material price volatility. This list of strengths can be used by animal feed business unit in XYZ Company to achieve their competitive advantage.

To determine the level of a company's ability in managing of any resources or the potential source of competitive advantage, an assessment of the "Organization" in the VRIO framework based on the Likert scale are presented in Table 2.

Based on the results of organizational level analysis, the competitiveness used for companies to create a sustainable competitive advantage are: (1). A strong brand identity has been recognized in a longer time as high quality animal feed producer (2). An extensive marketing networks, (3). Technical support services reliable and well experienced, and (4) Good corporate financial management capabilities.

Table-2. Assessment of Organization Scale

\begin{tabular}{|c|c|c|c|c|c|c|}
\hline \multirow[t]{2}{*}{ Resources/Capabilities } & \multicolumn{4}{|c|}{$\begin{array}{l}\text { Organization } \\
\text { Scale }\end{array}$} & \multirow{2}{*}{$\begin{array}{l}\text { Organization } \\
\text { Level of } \\
\text { Capability }\end{array}$} & \multirow[t]{2}{*}{$\begin{array}{l}\text { Competitive } \\
\text { Implication }\end{array}$} \\
\hline & 1 & 2 & 3 & 4 & & \\
\hline Clear Mission and Objective of the Animal Feed Business & $\mathrm{O}$ & 1 & 6 & $\mathrm{O}$ & $71 \%$ & $\begin{array}{l}\text { Temporary } \\
\text { Competitive } \\
\text { Advantage } \\
\end{array}$ \\
\hline Big Corporate Loan capacity & O & $\mathrm{O}$ & 6 & 1 & $79 \%$ & $\begin{array}{l}\text { Temporary } \\
\text { Competitive } \\
\text { Advantage }\end{array}$ \\
\hline Big corporate asset and capital & 0 & 0 & 3 & 4 & $89 \%$ & $\begin{array}{l}\text { Temporary } \\
\text { Competitive } \\
\text { Advantage }\end{array}$ \\
\hline Advanced factory technology and facility & $\mathrm{O}$ & $\mathrm{O}$ & 4 & 3 & $86 \%$ & Competitive Parity \\
\hline Good spatial arrangement of the animal feed factory & O & 1 & 4 & 2 & $79 \%$ & Competitive Parity \\
\hline Strategic location of the animal feed factory & O & $\mathrm{O}$ & 3 & 4 & $89 \%$ & Competitive Parity \\
\hline The reliable capability of $\mathrm{R} \& \mathrm{D}$ in creating livestock feed formula & $\mathrm{O}$ & $\mathrm{O}$ & $\mathrm{O}$ & 7 & $100 \%$ & $\begin{array}{l}\text { Proceed to } \\
\text { organization } \\
\text { analysis }\end{array}$ \\
\hline Qualified and well experienced experts of the company & $\mathrm{O}$ & $\mathrm{O}$ & 2 & 5 & $93 \%$ & $\begin{array}{l}\text { Temporary } \\
\text { Competitive } \\
\text { Advantage }\end{array}$ \\
\hline Loyalty of the company employees & $\mathrm{O}$ & $\mathrm{O}$ & 7 & $\mathrm{O}$ & $75 \%$ & Competitive Parity \\
\hline Employees motivation & O & $\mathrm{O}$ & 6 & 1 & $79 \%$ & Competitive Parity \\
\hline Sophistication of finished goods technology & $\mathrm{O}$ & $\mathrm{O}$ & 4 & 3 & $86 \%$ & Competitive Parity \\
\hline Sophistication of raw materials quality control technology & $\mathrm{O}$ & $\mathrm{O}$ & 2 & 5 & $93 \%$ & $\begin{array}{l}\text { Temporary } \\
\text { Competitive } \\
\text { Advantage }\end{array}$ \\
\hline Sophistication of finished goods quality control technology & O & $\mathrm{O}$ & 5 & 2 & $82 \%$ & Competitive Parity \\
\hline Supplier loyalty & $\mathrm{O}$ & $\mathrm{O}$ & 6 & 1 & $79 \%$ & Competitive Parity \\
\hline Raw materials transportation system & $\mathrm{O}$ & $\mathrm{O}$ & 6 & 1 & $79 \%$ & Competitive Parity \\
\hline Big raw materials warehouse storage capacity & 0 & 0 & 3 & 4 & $89 \%$ & $\begin{array}{l}\text { Temporary } \\
\text { Competitive }\end{array}$ \\
\hline
\end{tabular}




\begin{tabular}{|c|c|c|c|c|c|c|}
\hline & & & & & & Advantage \\
\hline Big production capacity of the company & $\mathrm{O}$ & $\mathrm{O}$ & 3 & 4 & $89 \%$ & $\begin{array}{l}\text { Temporary } \\
\text { Competitive } \\
\text { Advantage }\end{array}$ \\
\hline Good administration of the company & O & $\mathrm{O}$ & 3 & 4 & $89 \%$ & Competitive Parity \\
\hline $\begin{array}{l}\text { The lack of adequate transportation infrastructure for animal feed } \\
\text { distribution }\end{array}$ & $\mathrm{O}$ & 3 & 4 & $\mathrm{O}$ & $64 \%$ & $\begin{array}{l}\text { Competitive } \\
\text { Disadvantage }\end{array}$ \\
\hline Finished Goods warehouse storage capacity & 1 & $\mathrm{O}$ & 5 & 1 & $71 \%$ & Competitive Parity \\
\hline $\begin{array}{l}\text { A strong brand identity has been recognized in a longer time as } \\
\text { high quality animal feed producer }\end{array}$ & $\mathrm{O}$ & $\mathrm{O}$ & $\mathrm{O}$ & 7 & $100 \%$ & $\begin{array}{l}\text { Proceed to } \\
\text { organization } \\
\text { analysis }\end{array}$ \\
\hline Credit Term is too short & 4 & $\mathrm{O}$ & 2 & 1 & $50 \%$ & $\begin{array}{l}\text { Competitive } \\
\text { Disadvantage }\end{array}$ \\
\hline Product pricing is the most expensive in its class & $\mathrm{O}$ & 5 & 2 & $\mathrm{O}$ & $57 \%$ & $\begin{array}{l}\text { Competitive } \\
\text { Disadvantage }\end{array}$ \\
\hline An extensive marketing networks & $\mathrm{O}$ & $\mathrm{O}$ & 3 & 4 & $89 \%$ & $\begin{array}{l}\text { Proceed to } \\
\text { organization } \\
\text { analysis }\end{array}$ \\
\hline Position as market leader & 1 & 1 & 4 & 1 & $68 \%$ & $\begin{array}{l}\text { Temporary } \\
\text { Competitive } \\
\text { Advantage }\end{array}$ \\
\hline Product assurance and guarantee & $\mathrm{O}$ & $\mathrm{O}$ & 5 & 2 & $82 \%$ & Competitive Parity \\
\hline Technical support reliable and well experienced & $\mathrm{O}$ & $\mathrm{O}$ & 2 & 5 & $93 \%$ & $\begin{array}{l}\text { Proceed to } \\
\text { organization } \\
\text { analysis }\end{array}$ \\
\hline CSR to the community/academic/farmers & $\mathrm{O}$ & $\mathrm{O}$ & 6 & 1 & $79 \%$ & Competitive Parity \\
\hline Good corporate financial management capability & $\mathrm{O}$ & $\mathrm{O}$ & 2 & 5 & $93 \%$ & $\begin{array}{l}\text { Proceed to } \\
\text { organization } \\
\text { analysis }\end{array}$ \\
\hline Ability for retaining company employees from Hijacking & $\mathrm{O}$ & $\mathrm{O}$ & 6 & 1 & $79 \%$ & Competitive Parity \\
\hline $\begin{array}{l}\text { Ability to improve the quality of employees' skill (training, } \\
\text { seminars, etc.) }\end{array}$ & $\mathrm{O}$ & 1 & 4 & 2 & $79 \%$ & Competitive Parity \\
\hline Ability to adopt the latest Information Technology system & $\mathrm{O}$ & $\mathrm{O}$ & 1 & 6 & $96 \%$ & Competitive Parity \\
\hline Ability to anticipate raw material price volatility & $\mathrm{O}$ & $\mathrm{O}$ & 7 & $\mathrm{O}$ & $75 \%$ & $\begin{array}{l}\text { Temporary } \\
\text { Competitive } \\
\text { Advantage }\end{array}$ \\
\hline Lack of ability to continuously obtain high quality raw materials & $\mathrm{O}$ & 2 & 4 & 1 & $71 \%$ & $\begin{array}{l}\text { Competitive } \\
\text { Disadvantage }\end{array}$ \\
\hline Speed in unloading of raw materials & $\mathrm{O}$ & 1 & 1 & 5 & $89 \%$ & Competitive Parity \\
\hline Ability to improve production efficiency & $\mathrm{O}$ & 1 & 3 & 3 & $82 \%$ & Competitive Parity \\
\hline The lack of ability to promote the product & $\mathrm{O}$ & 2 & 4 & 1 & $71 \%$ & $\begin{array}{l}\text { Competitive } \\
\text { Disadvantage }\end{array}$ \\
\hline
\end{tabular}

Source: Researcher's approach, 2018

\section{Conclusion}

Resource Based View approach is a managerial framework used to determine the competitive advantage with the potential to deliver sustainable competitive advantage to a firm. It is recommended to combine the value chain analysis with VRIO framework and Likert measurement scale in order to measure the level of proficiency of a company in managing resources/capabilities as a source of its competitive advantage. Therefore, the company's management able to conduct an accurate performance improvement of a potential resources or capabilities to build sustained competitive advantage in the business.

It is suggested that further research on the use a combination of VRIO framework with Likert scale for corporate strategic planning activities. In all the suggestions mentioned, that combination could be used in many business areas.

\section{References}

Amit, J. and P.J.H. Schoemaker, 1993. Strategic assets and organizational rent. Strategic Management Journal, 14(1): 33-46. View at Google Scholar | View at Publisher

Barney, J.B., 1991. Firm resources and sustained competitive advantage. Journal of Management, 17(1): 99-120. View at Google Scholar $\mid$ View at Publisher

Barney, J.B., 1995. Looking inside for competitive advantage. Academy of Management, 9(4): 49-61. View at Google Scholar $\mid$ View at Publisher

Barney, J.B., 2001. Is the resource-based "view" a usefull perspective for strategic management research ? Yes. Academy of Management Review, 26(1): 41-56. View at Google Scholar | View at Publisher

Becker, G., 1964. Human capital: A theoretical and empirical analysis, with special reference to education. New York: National Bureau of Economic Research/Columbia University Press.

Chaharbaghi, K. and R. Lynch, 1999. Sustainable competitive advantage: Towards a dynamic resource-based strategy. Management Decision, 37(1): 45-50. View at Google Scholar | View at Publisher

David, F., 2013. Strategic management: A competitive advantage approach, concepts \& cases. 15th Edn., New Jersey: Prentice Hall.

Ghemawat, P., 1986. Sustainable advantage. Harvard Business Review, 64(5): 53-58. View at Google Scholar

Grant, R.M., 1991. The resource-based theory of competitive advantage: Implications for strategy formulation. California Management Review, 33(3): 114-135.

Grant, R.M., 2013. Contemporary strategy analysis. 8th Edn., West Sussex: John Wiley \& Sons Ltd.

Knot, P.J., 2015. Does VRIO help managers evaluate a form's resource. Management Decision, 53(8): 1806-1822. View at Google Scholar $\mid$ View at Publisher

Kraaijenbrik, J., J.C. Spender and A.J. Groen, 2010. The resource-based view: A review and assesment of it's critique. Journal of Management, 36(1): 349-372. View at Google Scholar

Mata, F.J., W.L. Fuers and J.B. Barney, 1995. Information technology and sustained competitive advantage: A resource-based analysis. MIS Quarterly, 19(4): 487-505. View at Google Scholar | View at Publisher 
Mohamad, F.A.Z. and S. Norezam, 2012. Understanding the concept of dynamic capabilities by dismantling Teece, Pisano and Shuen (1997)'s definition. International Journal of Academic Reseach in Business and Social Sciences, 2(8): 367-368. View at Google Scholar

Newbert, S.L., 2007. Empirical research on the resource-based view of the firm: An assesment ad suggestions for future research. Strategic Management Journal, 28(2): 121-146. View at Google Scholar | View at Publisher

Peteraf, M.A., 1993. The cornerstone of competitive advantage: A resource-based view. Strategic Management Journal, 14(3): 179-191. View at Google Scholar | View at Publisher

Porter, M., 1998. Competitive strategy: Techniques for analyzing industries and competitors. New York: Free Press.

Sirmon, D.G., M.A. Hitt and R.D. Ireland, 2007. Managing firm resources in dynamic environmnets to create value: Looking inside the black box. Academy of Management Review, 32(1): 273-292. View at Google Scholar | View at Publisher

Teece, D.J., G. Pisano and A. Shuen, 1997. Dynamic capabilities and strategic management. Strategic Management Journal, 18(7): 509-533. View at Google Scholar $\mid$ View at Publisher

Tomer, J., 1987. Organizational capital: The path to higher productivity and well-being. New York: Praeger.

Wernerfelt, B., 1984. A resource based view of the firm. Strategic Management Journal, 5(2): 171-180. View at Google Scholar

Wernerfelt, B., 2013. On the role of the RBV in marketing. Journals of the Academic Marketing Science, 42(1): 22-23.

Williamson, 1975. Markets and hierarchies: Analysis and antitrust implications. New York: Free Press.

Citation | Widya Ariyani; Arief Daryanto; Sahara (2018). Operationalization of Internal Analysis Using the VRIO Framework: Development of Scale for Resource and Capabilities Organization (Case Study: XYZ Company Animal Feed Business Unit). Asian Business Research Journal, 3: 9-14.

History:

Received: 24 April 2018

Revised: 21 May 2018

Accepted: 30 May 2018

Published: 4 June 2018

Licensed: This work is licensed under a Creative Commons

Attribution 3.0 License (oc)

Publisher: Eastern Centre of Science and Education
Acknowledgement: All authors contributed to the conception and design of the study.

Funding: This study received no specific financial support.

Competing Interests: The authors declare that they have no conflict of interests.

interests. Transparency: The authors confirm that the manuscript is an honest,
accurate, and transparent account of the study was reported; that no vital accurate, and transparent account of the study was reported; that no vital
features of the study have been omitted; and that any discrepancies from the study as planned have been explained.

Ethical: This study follows all ethical practices during writing.

Eastern Centre of Science and Education is not responsible or answerable for any loss, damage or liability, etc. caused in relation to/arising out of the use of the content. Any queries should be directed to the corresponding author of the article. 